\title{
The Use of Excel Statistics for Research Data Processing for Teachers of SMAN 3 Barru, Barru Regency
}

\section{Penggunaan Statistika Excel Untuk Pengolahan Data Penelitian Bagi Guru SMAN 3 Barru Kabupaten Barru}

\author{
R. Rusli ${ }^{\mathrm{a},}$, Abdul Rahman ${ }^{\mathrm{a}}$, Hamzah Upu ${ }^{\mathrm{a}}$, Ansari Saleh Ahmar ${ }^{\mathrm{b}}$, \& H. Hastuty ${ }^{\mathrm{c}}$ \\ ${ }^{a}$ Department of Mathematics, Universitas Negeri Makassar, Indonesia \\ ${ }^{b}$ Department of Statistics, Universitas Negeri Makassar, Indonesia \\ ${ }^{c}$ Department of Mathematics, Universitas Muhammadiyah Parepare, Indonesia
}

\begin{abstract}
This activity was carried out with the aim of: (1) Increasing teacher knowledge in processing and analyzing research data; (2) Developing teacher awareness and knowledge about the importance of data management in research data analysis; (3) Improving the insight, ability and skills of teachers in utilizing data to make it more informative by analyzing data using excel software; and (4) Reducing the number of teachers who perform data processing and analysis intuitively and manually in the computing era. The results of the implementation of this activity were: (1) The knowledge of teachers in processing and analyzing research data was increased; (2) The awareness and knowledge of teachers about the importance of processing and analyzing research data were developed; (3) The insight, ability and skills of teachers in utilizing data to be more informative with proper data processing and analysis were improved; and (4) The number of teachers who perform data processing and analysis intuitively and manually in the computing era was reduced.
\end{abstract}

\begin{abstract}
Abstrak
Kegiatan ini bertujuan kegiatan ini adalah untuk: (1) Meningkatkan pengetahuan guru dalam pengolahan dan menganalisis data penelitian; (2) Meningkatkan kesadaran dan pengetahuan pada guru tentang pentingnya pengelolaan data dalam analisis data penelitian; (3) Meningkatkan wawasan, kemampuan, dan keterampilan guru dalam memanfaatkan data menjadi lebih informatif dengan analisis data menggunakan perangkat lunak excel; dan (4) Mengurangi jumlah guru yang melakukan pengolahan dan analisis data secara intuisi dan manual di era komputasi. Hasil dari kegiatan ini adalah: (1) Menambah pengetahuan guru dalam pengolahan dan dalam menganalisis data penelitian; (2) Meningkatnya kesadaran dan pengetahuan pada guru tentang pentingnya pengolahan dan analisis data penelitian; (3) Meningkatnya wawasan, kemampuan, dan keterampilan guru dalam memanfaatkan data menjadi lebih informatif dengan pengolahan dan analisis data yang tepat; dan (4) Mengurangi jumlah guru yang melakukan pengolahan dan analisis data secara intuisi dan manual di era komputasi.
\end{abstract}

(C) 2020 Author(s).

Keywords: Excel, Toolspack Analysis, Statistics.

\section{Pendahuluan}

Semangat guru membuat karya tulis ilmiah rendah, ini dikarenakan beberapa hal diantaranya adalah kesibukan sehari-hari mengajar baik yang menjadi tugas pokonya di tempat bertugas maupun sebagau tugas tambahan di sekolah

\footnotetext{
* Corresponding author:

E-mail address: rusli.siman@unm.ac.id (R. Rusli)
} 
lain, belum pahamnya guru bahwa data yang ada disekitarnya khususnya data dari siswa harus diolah menjadi informasi penting, kurang mengertinya guru-guru tersebut untuk mengolah data yang dimilikinya sehingga menjadi informasi, juga dikarenakan pengetahuan yang dimiliki tentang alat-alat pengolahan data, misalnya perangkat lunak statistik, penyebab lain adalah kurang pahamnya menentukan statistik yang tepat untuk mengolah data sesuai tujuan yang diinginkan. Kondisi ini harus segera di tindak lanjuti sedini mungkin agar kelemahan-kelemahan tersebut semakin tereliminir. Guru sebagai tenaga pendidikan mempunyai peranan yang penting dan mendasar, selain mampu memberikan pembelajaran berbasis teori, juga guru mampu terampil dalam berkarya, khususnya karya tulis ilmiah yang ditulis dari suatu penelitian yang dilakukannya untuk peningkatan hasil belajar siswa, juga untuk eksistensi dirinya sebagai guru yang harus mengajar, mendidik, dan menjadi contoh baik dari sikap dan perilaku leh siswanya. Dan tentunya hal ini akan berpengaruh terhadap hasil belajar siswa (Rahman, Ahmar, \& Rusli, 2016). UU No. 20 tahun 2003 tentang system pendidikan nasional mengisyaratkan adanya pendidikan yang bermutu, pendidikan yang bermutu tersebut sangat dipengaruhi oleh oleh guru sebagai tokoh sentral dalam penyelenggaraan pendidikan.

Kompetensi menghasilkan karya tulis bagi seorang guru merupakan kompetensi utama selain mengajar, karena tuntutan adanya kredit dari karya ilmiah untuk kenaikan pangkat dan jabatan guru. Kemampuan dan kepekaan guru melihat keadaan siswa dan sekitarnya perlu dilatih dan diasah terus menerus agar menjadi suatu pembiasaan positif dan menjadikan pengalaman yang baik dalam berkarya, terutama dalammeneliti dan menuliskan temuannya dengan baik dan benar, dengan demikain pemahaman guru terhadap keadaan sekitarnya menjadi baik. Kompetensi lainnya adalah guru dituntut pula agar mampu mendesiminasikan hasil penelitiannya dalam pengajarannya. Kemampuan memahami data dan analisis statistika serta keterampilan menggunakan perangkat lunak statistik diharapkan mampu meningkatkan motivasi guru melakukan penelitian.

Pemilihan perangkat lunak excel sebagai alternatif dalam pengolahan data penelitian dengan menggunakan paket statistika yang dimiliki oleh excel, karena aplikasi ini sangat dikenal oleh guru-guru. Guru-guru kita di Indonesia, khususnya Sulawesi Selatan pada umumnya menggunakan perangkat lunak microsoft office sebagai alat bantu dalam menyelesaikan tugas-tugasnya sebagai guru.

Microsoft Excel adalah sebuah program aplikasi lembar kerja spreadsheet yang dibuat dan didistribusikan oleh Microsoft Corporation untuk sistem operasi Microsoft Windows dan Mac OS. Software ini dikenal juga sebagai Microsoft Office Excel, MS. Excel atau sering disebut sebagai Excel saja. Oleh sebab itu syarat utama untuk bisa menggunakan program aplikasi excel ini, komputer yang anda gunakan harus sudah terinstal sistem operasi (operating sistem) Windows atau Mac terlebih dahulu. Microsoft Excel adalah salah satu dari sekian banyak Program Aplikasi yang terdapat dalam paket Microsoft Office (Oakley, 2014; Harvey, 2011).

Salah satu hal yang membuat aplikasi Excel cukup terkenal adalah kelengkapan fitur Formulas dan Functions yang lebih kita kenal dengan istilah rumus excel. Formula dan fungsi ini digunakan untuk membantu kita dalam mengerjakan beragam proses perhitungan data secara cepat, tepat dan semi otomatis. Formula excel bisa dgunakan dalam perhitungan yang sederhana sampai kalkulasi yang kompleks, baik untuk data berbentuk angka, data teks, data tanggal, data waktu, atau kombinasi dari data-data tersebut (Guerrero, 2019; Salkind \& Frey, 2019).

Pada Microsoft excel kita bekerja dengan system workbook, sedangkan di dalam workbook terdapat worksheet atau lembar kerja yang biasanya cukup kita sebut sheet saja. Jika workbook adalah sebuah buku maka worksheet adalah lembaran-lembaran kertas dalam buku tersebut. Pada worksheet ini kita bekerja dengan menggunakan kolom dan baris yang membentuk kotak kecil-kecil berupa sel-sel (cells) tempat kita memasukkan data.

Microsoft excel merupakan salah satu aplikasi yang termasuk dalam paket mikrosoft office bersama dengan microsoft word, powerpoint dan lainnya dengan demikian boleh dikatakan bahwa setiap guru yang memiliki komputer baik itu komputer destop, laptop maupun notebook tentulah dalam perangkat komputer yang dimilikinya tersebut telah terinstal microsoft excel sebagai bagian dari microsoft office. Fasilitas analisis statistika yang dimiliki oleh excel tidak otomatis aktif, hal inilah penyebab mengapa fasilitas tersenbut jarang digunakan oleh orang kebanyakan. Paket 
statistika excel terdapat dalam paket addons analisis toolspack yang harus diaktifkan sebelum digunakan, dan cara mengaktifkan juga sangat mudah.

Berdasarkan uraian di atas, dipertimbangkan perlu dilakukan kegiatan pelatihan pengolahan data penelitian menggunakan perangkat lunak excel. bagi para guru, dikhususkan bagi guru-guru Sekolah Menegah Atas Negeri 3 Barru,. difokuskan pada peningkatan kemampuan memahami cara menggunakan statistik secara tepat dan mampu menggunakan perangkat lunak excel, dalam hal ini paket statistik yang dimiliki excel dalam mengolah dan menganalisis data penelitian. Harapannya, setelah pelatihan guru-guru menjadi lebih produktif dalam menghasilkan penelitian yang dapat di manfaatkan dalam pengajaran secara khusus dan dalam pengambilan keputusan secara umum. Dalam rangka memenuhi kebutuhan Guru-Guru tersebut dalam memahami pengelolaan data statistik dan analisisnya, maka kami memandang perlu melakukan kegiatan pelatihan yang disasarkan kepada guru-guru sekolah menegah atas di kabupaten Barru, khususnya SMAN 3 Barru.

Pelaksanaan pelatihan ini berdasarkan uraian di atas, terindikasi bahwa permasalahan mitra adalah 1) kurangnya minat dan motivasi guru menulis melakukan penelitian, 2) kurangnya minat dan motivasi guru untuk menulis karya tulis ilmiah, 3) kurangnya pemahaman guru tentang cara pengolahan data secara statistik, 4) kurangnya keterampilan guru penggunaan perangkat lunak statistika, 5) belum optimalnya pemanfaatn data yang ada untuk menjadi informasi.

Permasalahan yang dihadapi oleh guru-guru mitra ini akan diselesaikan melalui pelatihan pengenalan toolspack data analisis perangkat lunak microsoft excel yang berisi paket statististika dan penggunaannya dalam mengolah data hasil penelitian baik penelitian kualitatif, penelitian tindakan kelas, dan penelitian kuantitatif.

Target luaran yang akan dihasilkan dari kegiatan ini secara umum adalah guru-guru SMAN 3 Barru yang menjadi objek tindakan semakin mengenali perangkat lunak excel dan mahir menggunakan toolspack analysis excel dalam pengolahan data, mampu memilih statistik yang tepat untuk mengolah data sesuai tujuan yang diinginkan, serta mampu melakukan interpretasi terhadap hasil analisis

\section{Metode Pelaksanaan}

Permasalahan yang dihadapi oleh mitra dalam hal ini guru-guru SMAN 3 Barru, sebagaimana diutarakan di atas, akan diselesaikan dalam bentuk pelatihan, kegiatan ini dilakukan dalam dalam bentuk 1) penyajian materi, 2) praktikum terbimbing, dan 3) presentasi.

Pada tahap penyajian materi, peserta diberi materi-materi mengenai konsep pengujian hipotesis statistik, jenis statistik yang tepat untuk pengujian komparasi dan korelasional, dan cara mengaktifkan paket toolspack analysis pada perangkat lunak excel. Pada tahap kegiatan praktikum peserta melakukan kegiatan praktek terbimbing pengaktifan toolspack analysis dan fitur-fitur statistika yang terdapat pada toolspack analysis excel.

Setelah itu, peserta melakukan presentasi dan diskusi tentang apa yang telah dikembangkan dalam praktikum pengolahan data penelitian dengan paket statistika yang terdapat dalam toolspack analysis excel tersebut. Adapun kegiatan ini dilaksanakan di ruang pertemuan dinas pendidikan kabupaten Takalar, dengan melibatkan peserta sebanyak 33 orang. Untuk memperoleh informasi sejauhmana respon peserta kegiatan PKM materi yang diberikan, dilengkapi dengan instrumen, yaitu angket respon terhadap pelaksanaan kegiatan. Selama proses, pelatihan anggota tim pengabdi melakukan dokumentasi berupa photo selama kegiatan pelatihan berlangsung.

\section{Metode Pelaksanaan}

Analysis Toolpak merupakan sebuah add-ins yng tersedia pada microsoft excel mulai versi 2007 sapai sekarang ini. Dalam Analysis Toolpak terdapat beberapa fasilitas untuk menganalisis data seperti Anova: Single Factor, Anova: Two Factor With Replication, Anova: Two Factor Withot Replication, Correlation, Covariance, Descriptive Statistics, 
Exponential Smoothing, F-Test Two-Sample for Variances, Fourier Analysis, Histogram, Moving Average, Random Number Generation, Rank and Percentile, Regression,Sampling,t-Test : Paired Two Sample for Means, t-Test : Two Sample Asumming Equal Variances, t-Test : Two Sample Asumming Unequal Variances.

Untuk mengaktifkan Add-Ins Analysis Toolpak di Excel langkah pertama Klik tombol Office, lalu Pilih Excel Options, Pada window Excel Options pilih Add Ins Pada bagian Manage pilih Excel Add Ins , kemudian klik Go, Akan muncul kotak dialog Add Ins Centang Analysis ToolPack lalu Klik OK. Jika muncul pesan "Microsoft Office Excel can't run tthis add in, This feature is not currently installed. Would you like to install it now? Klik Yes. Akan muncul window configuration progress tunggu hingga proses instal add-ins selesai. Jika berhasil menginstal Add-in terebut, maka di exel akan muncul ribbon menu baru, yaitu Data Analysis. Tampilan fitur yang terdapat dalam Data Analysis bisa dilihat pada fig. 1 .

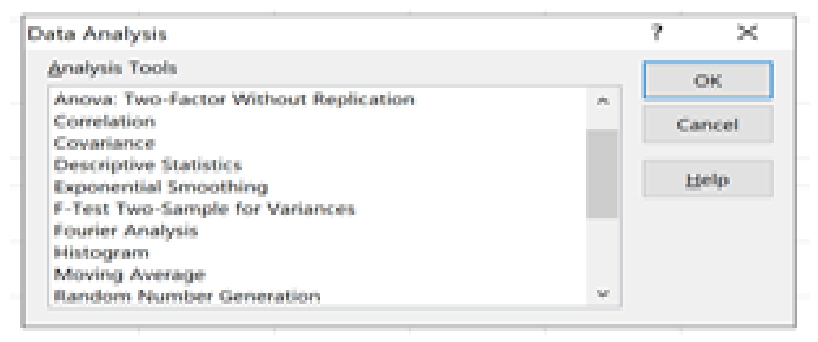

Fig. 1 Fitur Data Analysis di Excel

Hasil dari kegiatan pelatihan ini guru-guru SMAN 3 Barru sebagai peserta, telah mampu dan terampil melakukan analisis data secara deskriptif, membuat tabel distribusi frekuensi, juga terampil dlam melakukan uji komparasi diantaranya adalah uji t sampel berpasangan, uji t sampel independen, anavar satu jalur maupun dua jalur, demikian juga untuk menguji analisis korelasional, meliputi uji korelasi, uji regresi linear sederhana, maupun regresi linear ganda. Kemampuan guru tersebut kami sajikan hanya beberapa sebagai contoh kemampuan yang telah dimiliki, kemampuan tersebut diantaranya adalah kemampuan dalam membuat ringkasan data. Untuk melakukan ringkasan data dilakukan pada menu statistika deskriptif excel pada fig. 2.

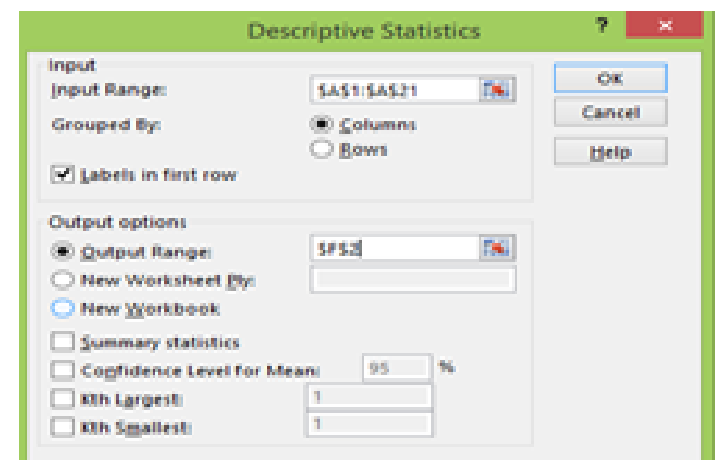

Fig. 2 Menu statistika deskriptif di Excel

Guru-guru tersebut juga terampil untuk membuat daftar distribusi frekuensi melalui menu histogram dari excel (fig. $3)$. 


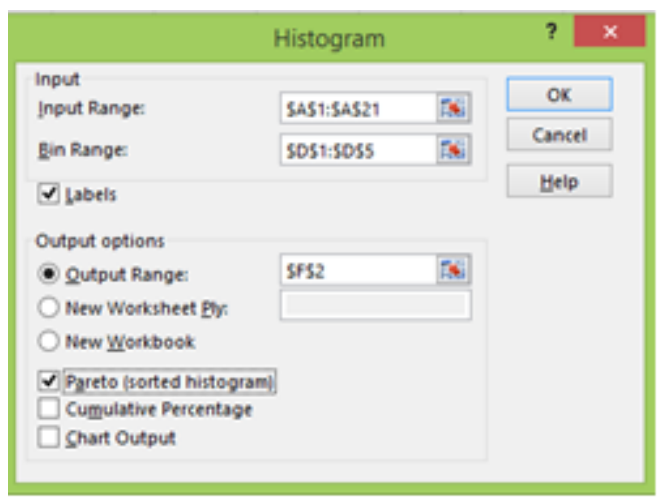

Fig. 3 Menu histogram di Excel

Hasil dari instruksi ini dapat dilihat fig. 4.

\begin{tabular}{|c|c|}
\hline Ranged & Frequency \\
\hline $45 a$ & $1 a$ \\
\hline $55 a$ & $0 a$ \\
\hline $65 a$ & $4 a$ \\
\hline $75 a$ & $6 a$ \\
\hline Morea & $9 a$ \\
\hline
\end{tabular}

Fig. 4 Hasil output histogram di Excel

Hasil di atas dapat dibaca bahwa rentang nilai yang lebih kecil dan sama dengan 45 sebanyak 1, rentang 46 - 55 sebanyak 0, rentang 56-65 sebanyak 4, rentang 66 - 75 sebanyak 6, dan di atas 75 sebanyak 9.

Kemampuan guru menggunakan statistik uji dengan menggunakan statistika excel, diantaranya uji paired t test seperti disajikan pada fig. 5 .

\begin{tabular}{|c|c|c|}
\hline \multicolumn{2}{|c|}{ t-Test: Paired Two Sample for Means } & \multirow[b]{2}{*}{ Sesudah } \\
\hline & Sebelum & \\
\hline Mean & 66 & 86 \\
\hline Variance & 54,4444444 & 15,55555556 \\
\hline Observations & 10 & 10 \\
\hline Pearson Correlation & 0,15272071 & \\
\hline Hypothesized Mean Difference & 45 & \\
\hline df & 9 & \\
\hline t Stat & $-26,293795$ & \\
\hline$P(T<=t)$ one-tail & $4,0196 E-10$ & \\
\hline t Critical one-tail & 1,83311293 & \\
\hline$P(T<=t)$ two-tail & $8,0392 E-10$ & \\
\hline t Critical two-tail & 2,26215716 & \\
\hline
\end{tabular}

Fig. 5 Hasil output Uji Paired t-test di Excel 
Hasil dari instruksi excel di atas dapat dilihat pada gambar di samping, yang merupakan hasil uji paired t test atau yang sering dikenal dengan uji t sampel berpasangan.

Kemampuan guru-guru SMAN3 Barru dalam mengolah data dalam regresi linear ganda dapat dilihat pada fig. 6 .

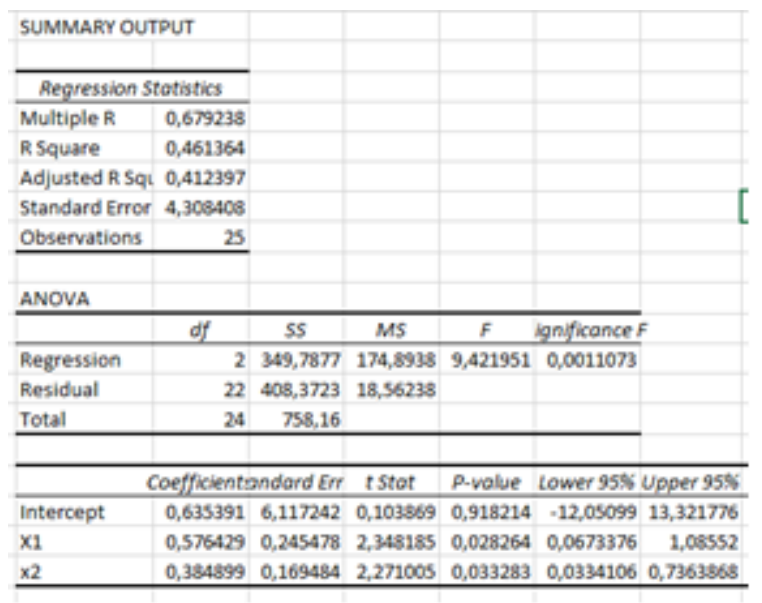

Fig. 6 Hasil output Regresi linear berganda di Excel

\section{Kesimpulan}

Kegiatan PKM yang dilaksanakan di SMAN3 Barru Kabupaten Takalar dengan menyajikan penggunaan Statistika Toolspack Analysis yang terdapat pada perangkat lunak excel bagi guru guru sekolah lanjutan pertama di kabupaten Takalar mendapatkan respons yang positif terbukti dengan semangatnya mereka mengikuti pelatihan.

Pelatihan ini memberikan hasil bahwa guru-guru mampu menggunakan toolpack analysisi atau paket statistika yang dimiliki oleh excel dalam menagnalisis data penelitian atau sejenisnya. Statistik uji yang mampu digunakan oleh guruguru diantaranya Anova: Single Factor, Anova: Two Factor With Replication, Anova: Two Factor Withot Replication, Correlation, Covariance, Descriptive Statistics, F-Test Two-Sample for Variances, Fourier Analysis, Histogram, Regression, Sampling, t-Test : Paired Two Sample for Means, t-Test : Two Sample Asumming Equal Variances, t-Test : Two Sample Asumming Unequal Variances.

Hasil pengolahan data pada angket yang di berikan secara online, bahwa semua paket-paket yang diberikan terjadi perbedaan yang signifikan pada taraf kepercayaan $\alpha=0.05$ pada kemampuan guru. Dengan kata lain setelah pelatihankemampuan guru dalam melakukan pengujian data lebih baik daripada sebelum pelatihan.

\section{Acknowledgements}

Penulis mengucapkan terima kasih kepada Universitas Negeri Makassar dan terkhusus kepada Fakultas Matematika dan Ilmu Pengetahuan Alam, Universitas Negeri Makassar, yang telah memberikan dana PNBP Tahun 2020 untuk pelaksanaan kegiatan ini.

\section{References}

Oakley, B. A. (2014). A mind for numbers: How to excel at math and science (even if you flunked algebra). TarcherPerigee. 
Harvey, G. (2011). Excel 2003 all-in-one desk reference for dummies. John Wiley \& Sons.

Guerrero, H. (2019). Modeling and Simulation: Part 2. In Excel Data Analysis (pp. 265-310). Springer, Cham.

Salkind, N. J., \& Frey, B. B. (2019). Statistics for people who (think they) hate statistics: using Microsoft Excel 2016. Sage Publications, Incorporated.

Rahman, A., Ahmar, A., \& Rusli, R. (2016). The influence of cooperative learning models on learning outcomes based on students' learning styles. World Transactions on Engineering and Technology Education, 14(3). 